\title{
Immune regulation of human colonic electrolyte transport in vitro
}

\author{
W A Stack, S J Keely, D P O’Donoghue, A W Baird
}

\begin{abstract}
The role of lamina propria cells in regulating human colonic ion transport was investigated in vitro. Normal human colonic mucosae were mounted in Ussing chambers, and short circuit current changes ( $\triangle S C C)$ were monitored in response to immune cell activation. Antihuman immunoglobulin $E$ (anti-IgE) and formyl -Methionyl-Leucyl-Phenylalanine (fMLP) were used to stimulate mast cells and phagocytes respectively. Anti-IgE $(100 \mu \mathrm{g} / \mathrm{ml})$ and fMLP $(100 \mu M)$ evoked rapid onset, inward $\triangle$ SCC (mean (SEM) $\max \triangle$ SCC $19.3(2.8)$ and $29.4(4 \cdot 7)$ $\mu A / 0.63 \mathrm{~cm}^{2}$ respectively). A pharmacological approach was used to identify the charge carrying ion species and to characterise mediators involved in the SCC response. Responses to each secretagogue were significantly attenuated by bumetanide, indicating that the $\triangle$ SCC was at least partly due to electrogenic chloride secretion. Piroxicam reduced the $\Delta$ SCC to mast cell and phagocyte activation by $91.1 \quad(3.4) \%$ and $48.2 \quad(25 \cdot 2) \%$ respectively, implicating eicosanoids as mediators of the responses. Mepyramine $(100 \mu M)$ reduced the SCC responses to anti-IgE by $79.6(12.0) \%$ but did not significantly alter $\Delta$ SCC responses to fMLP. Desensitisation to repeated antiIgE or fMLP stimulation, and cross desensitisation between each of the stimuli, were features of immune cell activation. In summary, we have shown that activation of immune cells can stimulate electrogenic chloride secretion. Such events in vivo will result in gradient driven secretory diarrhoea, which may occur as a protective response to enteric-dwelling parasites, or as a feature of local bowel inflammation.
\end{abstract}

(Gut 1995; 36: 395-400)

Keywords: colon, mast cell secretion, phagocyte

Dharmacolt of University College

Dublin

$S$ J Keely

A W Baird

Department of Gastroenterology Gastroenterology
St Vincent's Hospital Dublin 4, Ireland W A Stack

D P O'Donoghue

Correspondence to: Dr A W Baird, Department of Pharmacology, University College Dublin, Belfield, College Dublin, B
Dublin 4, Ireland.

Accepted for publication 14 June 1994 ated lymphoid tissue has been directly implicated in the regulation of intestinal electrolyte transport. ${ }^{45}$ Type 1 hypersensitivity reactions in response to specific antigen(s) have been shown in a number of mammals other than man. ${ }^{6-8}$ Studies in both isolated animal colonic mucosa 9 and in colonic tumour derived cell lines ${ }^{10}$ have demonstrated that activation of mast cells in vitro provokes electrogenic chloride secretion. Such a sequence of events in vivo will lead to secretory diarrhoea. ${ }^{2} \mathrm{~A}$ similar potential involvement of phagocytes in stimulating electrogenic chloride secretion has been clearly established ${ }^{9}$ using tissues obtained from experimental animals. However, much less information is available on immunological regulation of intestinal ion transport in man.

We investigated the role of elements of the local immune system in regulating epithelial ion transport in human colonic mucosa. Anti-human IgE (anti-IgE) and a bacterial derived tri-peptide, formyl-Methionyl-LeucylPhenylalanine (fMLP), were used to activate colonic mast cells and phagocytes (neutrophils, eosinophils, and macrophages) respectively. ${ }^{1112}$ Electrogenic ion transport was observed in response to each of these stimuli. The loop blocking diuretic bumetanide was used to investigate whether short circuit current (SCC) responses were a consequence of electrogenic chloride secretion. Putative mediators were investigated using the histamine $\left(\mathrm{H}_{1}\right)$ receptor antagonist mepyramine and the cyclo-oxygenase inhibitor piroxicam.

\section{Methods}

Human colon was obtained at surgical resection for colonic carcinoma or diverticular disease. Tissues from the margin of each resection were immediately transferred to the laboratory in pre-oxygenated Krebs-Henseleit solution at $4^{\circ} \mathrm{C}$. The composition of this solution is (in $\mathrm{mmol} / \mathrm{l}$ ); $118 \mathrm{NaCl}, 4.7 \mathrm{KCl}, 2.5$ $\mathrm{CaCl}_{2}, \quad 1.2 \quad \mathrm{MgSO}_{4}, \quad 1.2 \quad \mathrm{KH}_{2} \mathrm{PO}_{4}, \quad 25$ $\mathrm{NaHCO}_{3}$, and $11 \cdot 1$ D-glucose. Right sided colonic specimens were taken from the ascending colon and left sided specimens from the distal sigmoid colon. The normal histological appearance of tissues was confirmed by routine pathological examination of samples obtained during dissection. The study was approved by the St Vincent's Hospital Ethics Committee.

Mucosal sheets, stripped of their underlying smooth muscle by blunt dissection, were mounted in Ussing chambers (window area $=0.63 \mathrm{~cm}^{2}$ ). Tissues, bathed on either side with $10 \mathrm{ml}$ of Krebs-Henseleit solution, maintained at $37^{\circ} \mathrm{C}$ and gassed with $95 \% \mathrm{O}_{2} / 5 \%$ $\mathrm{CO}_{2}$, were voltage clamped to zero potential difference using a DVC 1000 voltage clamp (World Precision Instruments, New Haven, CT). The SCC was monitored continuously using an analogue to digital data acquisition system (MacLab). Up to four sheets of mucosa were obtained from a single patient. Drugs were added to solutions bathing either the basolateral side or the apical side of the 
TABLE I Basal parameters in tissues from left and right sided colon (values, mean (SEM))

\begin{tabular}{lrr}
\hline & \multicolumn{1}{l}{ Right } & \multicolumn{1}{l}{ Left } \\
\hline SCC $(\mu \mathrm{A})$ & $62 \cdot 5(3 \cdot 8)(\mathrm{n}=37)$ & $53 \cdot 4(3 \cdot 2)(\mathrm{n}=91)^{\star}$ \\
TER $(\Omega)$ & $150 \cdot 4(9 \cdot 6)(\mathrm{n}=35)$ & $145 \cdot 8(5 \cdot 2)(\mathrm{n}=90)$ \\
PD $(\mathrm{mV})$ & $9 \cdot 3(0 \cdot 7)(\mathrm{n}=35)$ & $7 \cdot 7(0 \cdot 5)(\mathrm{n}=89)^{\star}$ \\
Response to & & \\
$\quad$ carbachol $(\mu \mathrm{A})$ & $54 \cdot 1(6 \cdot 0)(\mathrm{n}=31)$ & $57 \cdot 0(2 \cdot 9)(\mathrm{n}=89)$ \\
\hline
\end{tabular}

SCC = short circuit current; $T E R=$ transepithelial resistance;

$\mathrm{PD}=$ potential difference.
Resting $S C C$ and $P D$ values were significantly lower in left

Resting SCC and PD values were significantly lower in left
colon than right ( $p<0.05$ in each case). TER values and SCC responses to carbachol $(100 \mu \mathrm{M})$ were not different. ${ }^{\star} \mathrm{p}<0 \cdot 05$.

preparation. Tissues were allowed to establish a stable SCC before any procedure was carried out. Transepithelial resistance (TER) measurements were made by transient changes of membrane voltage over the range $\pm 4 \mathrm{mV}$ and application of the Ohmic relationship.

Polyclonal antibody raised in goats against human IgE (anti-IgE), was obtained from Nordic Immunological Laboratories, Maidenhead, Berks, UK and fMLP from Sigma Chemical Co, Poole, Dorset, UK. fMLP was dissolved in dimethyl-sulphoxide (BDH, Poole, Dorset, UK), divided into aliquots, stored at $-20^{\circ} \mathrm{C}$, and thawed before addition to the Ussing chambers. Vehicle control experiments were performed in tandem. Responses ( $\triangle$ SCC) were determined as the difference between the basal and the peak SCC observed after the addition of secretagogues. Preliminary concentration and effect studies showed a maximal response to anti-IgE $(100 \mu \mathrm{g} / \mathrm{ml})$ in Krebs-Henseleit solution and to fMLP at a concentration of $100 \mu \mathrm{M}$, and these concentrations were used throughout the study. At the end of each experiment, carbachol $(100 \mu \mathrm{M})$ was applied to the basolateral side of the mucosa to confirm tissue viability. Piroxicam, bumetanide, carbachol, prostaglandin $\mathrm{E}_{2}$, and mepyramine were obtained from Sigma Chemical Co, Poole, Dorset, UK.

Results are expressed for the SCC as $\mu \mathrm{A} / 0.63 \mathrm{~cm}^{2}$, for transepithelial resistance (TER) as $\Omega .0 .63 \mathrm{~cm}^{2}$, and for potential difference (PD) as $\mathrm{mV} / 0.63 \mathrm{~cm}^{2}$. All statistical analyses were performed on original data and are presented as mean (SEM). Statistically significant differences between mean values were assessed by means of Mann-Whitney (unpaired) or Wilcoxon's (paired) tests as appropriate. The Pearson method was used to determine correlations.

\section{Results}

BASAL PARAMETERS

After an equilibration period of at least 30 minutes, during which transients of basal electrical parameters were observed, all values stabilised (Table I). Carbachol $(100 \mu \mathrm{M})$ was used as a standard secretagogue at the end of each experiment to confirm tissue viability and as a quantitative marker of functional integrity. Responses to carbachol were not different for left and right side sources of tissue. Furthermore, there was no correlation between TER values and SCC responses to carbachol (correlation coefficient $=0.37$ ). Since responses to carbachol were similar in left and right colons, and with the limited amount of human tissue available, specimens from both sides were used to investigate the nature of immunological stimulation of ion transport.

\section{$\triangle$ SCC TO IMMUNE CELL ACTIVATION}

Anti-IgE $(100 \mu \mathrm{g} / \mathrm{ml})$ evoked a rapid onset, transient, inward $\triangle S C C$ when added to the basolateral side of the tissue (Fig 1A). Basolateral addition of fMLP $(100 \mu \mathrm{M})$ also caused a rapid onset, transient inward $\triangle S C C$ (Figure B). $\triangle$ SCC responses to anti-IgE or to fMLP were not significantly different in preparations obtained from left or right colon. Apical application of anti-IgE evoked a qualitatively similar but smaller $\triangle$ SCC (Table II). Apical side challenge with fMLP also evoked a smaller $\triangle$ SCC than when basolaterally applied, but this was not statistically significant (Table II). In separate experiments, pretreatment with apical fMLP, which evoked a $\triangle$ SCC of $18.2(4 \cdot 8) \mu \mathrm{A}$, attenuated the capacity of the tissue to respond to subsequent basolateral challenge with fMLP $(8 \cdot 7(4 \cdot 1) \mu \mathrm{A}$ compared
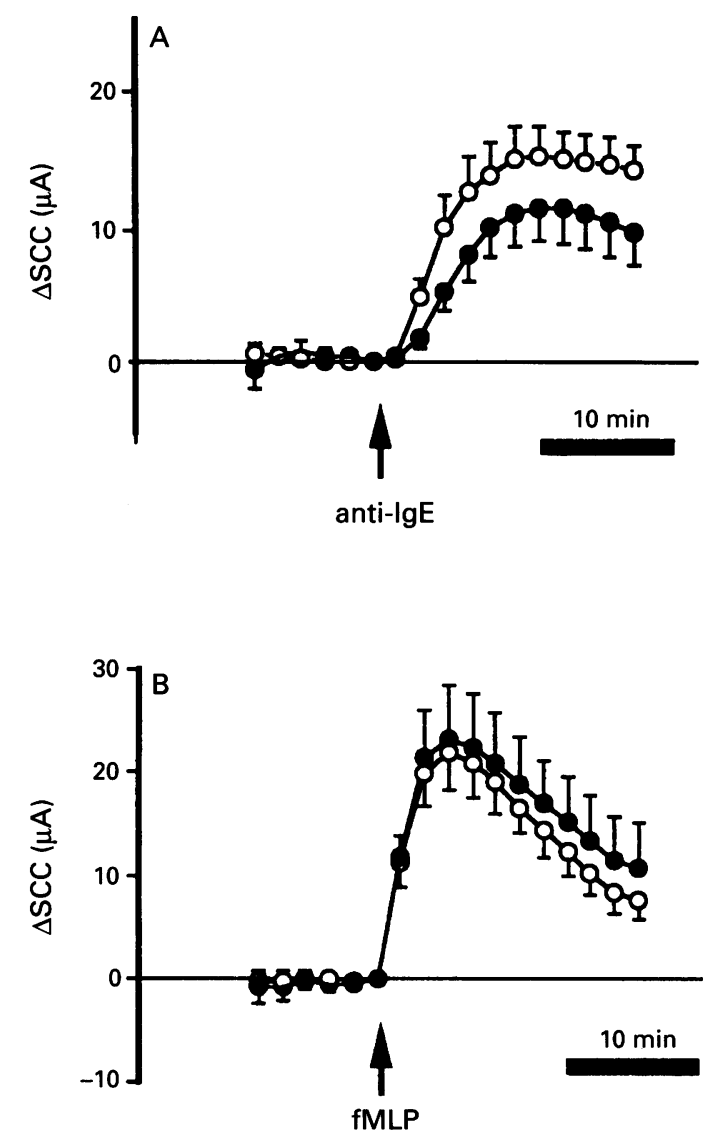

Composite short circuit current (SCC) versus time curves are shown to illustrate $(A)$ ion transport responses to anti-human immunoglobulin $E$ (anti-IgE) $(100 \mu \mathrm{g} / \mathrm{ml}$; basolaterally) added to left (open circles; $n=34$ ) and right (closed circles; $n=15$ ) voltage clamped colonic mucosae. The Figure (B) shows similar data for ion transport responses to formyl-Methionyl-Leucyl-Phenylalanine (fMLP) (100 $\mu M$; basolaterally) added to left (open circles; $n=29$ ) and right (closed circles; $n=14$ ) voltage clamped colonic mucosae. 
TABLE II Ion transport responses to anti-human immunoglobulin $E$ (anti-IgE) and fMLP in relation to site of application (values, mean (SEM))

\begin{tabular}{|c|c|c|}
\hline $\begin{array}{l}\text { Site of } \\
\text { application }\end{array}$ & $\begin{array}{l}\text { Response to anti- } \\
\operatorname{IgE}(100 \mu g / \mathrm{ml}) \\
\Delta S C C(\mu \mathrm{A})\end{array}$ & $\begin{array}{l}\text { Response to } \\
\text { fMLP }(100 \mu M) \\
\Delta S C C(\mu A)\end{array}$ \\
\hline $\begin{array}{l}\text { Apical } \\
\text { Basolateral }\end{array}$ & $\begin{array}{c}5 \cdot 4(2 \cdot 4)(n=5) \\
20 \cdot 3(4 \cdot 6)(n=5) \star\end{array}$ & $\begin{array}{l}18 \cdot 2(4 \cdot 8)(n=5) \\
27 \cdot 1(6 \cdot 9)(n=5)\end{array}$ \\
\hline
\end{tabular}

$\mathrm{fMLP}=$ formyl-Methionyl-Leucyl-Phenylalanine; $\Delta \mathrm{SCC}=$ short circuit current response.

Peak $\triangle$ SCC responses to anti-IgE and fMLP are compared with regard to apical or basolateral side application of each stimulus. Challenge was made first apically followed by

basolateral additions. Separate tissues were used to investigate each of the secretagogues.

${ }^{\star} \mathrm{p}<0.05$.

with $27 \cdot 1(6 \cdot 9) \mu \mathrm{A}$ in paired, control tissues; $\mathrm{p}<0.005, \mathrm{n}=5)$.

\section{IDENTIFICATION OF THE CHARGE CARRYING} ION

Bumetanide $(100 \mu \mathrm{M})$, a loop blocking diuretic which inhibits the basolateral $\mathrm{Na} / \mathrm{K} / \mathrm{Cl}$ cotransporter necessary for chloride secretion $^{13}$ added to the basolateral side of the tissue significantly reduced $\triangle \mathrm{SCC}$ responses to antiIgE by $72.3(10.5) \%$, and to fMLP by 56.2 $(12 \cdot 8) \%$ (Table III). Ion transport responses to $100 \mu \mathrm{M}$ carbachol $(50 \cdot 2 \mu \mathrm{A}(10 \cdot 2) ; \mathrm{n}=7)$ were significantly reduced by pretreatment with 100 $\mu \mathrm{M}$ bumetanide $(5.8(1.8) \mu \mathrm{A} ; \mathrm{p}<0.01)$.

DESENSITISATION AND CROSS DESENSITISATION BETWEEN STIMULI ARE FEATURES OF IMMUNE CELL ACTIVATION

In a single series of experiments, basolateral addition of anti-IgE $(100 \mu \mathrm{g} / \mathrm{ml})$ produced a peak $\Delta S C C$ of $26 \cdot 1(10.9) \mu A(n=5)$. When the SCC had returned to baseline, tissues were subjected to a second basolateral challenge with anti-IgE. The $\Delta \mathrm{SCC}$ was $1 \cdot 1(0 \cdot 4) \mu \mathrm{A}$, a $93.4(3.1) \%$ reduction in the response $(\mathrm{p}<0.005)$. In separate experiments using a similar design, basolateral fMLP $(100 \mu \mathrm{M})$ caused a $81.9(14.7) \%$ reduction in $\triangle S C C$ to a second addition (1st addition $34.9(13.6) \mu \mathrm{A}$; 2 nd addition $(6 \cdot 1(5 \cdot 5) \mu A ; n=5, p<0 \cdot 05)$. To determine if cross desensitisation occurs between anti-IgE and fMLP, tissues were basolaterally stimulated with anti-IgE followed by fMLP or in the opposite order. In fMLP pretreated tissues, $\triangle S C C$ responses to anti-IgE were significantly reduced by $50.1(12.9) \%$ $(n=6 ; p<0.05)$ compared with control, and for anti-IgE pretreated tissues, responses to fMLP were reduced by $39.7(11.5) \%$ compared

TABLE III Effect of bumetanide on short circuit current responses ( $\triangle S C C$ ) to anti-IgE and fMLP (values, mean (SEM))

\begin{tabular}{llc}
\hline Stimulus & $\begin{array}{l}\text { Control } \\
\Delta S C C\end{array} A A$ & $\begin{array}{l}\text { Bumetanide } \\
(100 \mu M) \\
\Delta S C C \mu A\end{array}$ \\
\hline Anti-IgE $(100 \mu \mathrm{g} / \mathrm{ml} ; \mathrm{n}=6)$ & $24 \cdot 1(9 \cdot 2)$ & $7 \cdot 12(2 \cdot 8)^{\star}$ \\
fMLP $(100 \mu \mathrm{M} ; \mathrm{n}=8)$ & $24.9(5 \cdot 6)$ & $14.6(5.9)^{\star}$
\end{tabular}

$\triangle S C C$ responses to anti-IgE and $\mathrm{MLLP}$ in bumetanide pretreated tissues are compared with paired controls. In each case, bumetanide significantly attenuated the ion transport response.
TABLE IV Effect of piroxicam pretreatment $(10 \mu M)$ on short circuit current responses ( $\triangle S C C$ ) to anti-IgE, fMLP, and prostaglandin $E_{2}$ (values mean (SEM))

\begin{tabular}{llc}
\hline Stimulus & $\begin{array}{l}\text { Control } \\
\Delta S C C\end{array}(\mu A)$ & $\begin{array}{l}\text { Piroxicam } \\
\Delta S C C(\mu A)\end{array}$ \\
\hline Anti-IgE $(100 \mu \mathrm{g} / \mathrm{ml} ; \mathrm{n}=5)$ & $16 \cdot 0(3 \cdot 0)$ & $1 \cdot 7(0 \cdot 9)^{\star \star}$ \\
fMLP $(100 \mu M ; \mathrm{n}=7)$ & $24 \cdot 5(6 \cdot 5)$ & $10 \cdot 4(5 \cdot 2)^{\star}$ \\
Prostaglandin $\mathrm{E}_{2}(10 \mu \mathrm{M} ; \mathrm{n}=7)$ & $15 \cdot 2(7 \cdot 2)$ & $54 \cdot 6(10 \cdot 4)^{\star \star}$ \\
\hline
\end{tabular}

$\triangle S C C$ responses to anti-IgE, fMLP, and prostaglandin $E_{2}$ in piroxicam pretreated tissues are compared with paired controls. Piroxicam significantly attenuated responses to anti-IgE and fMLP but enhanced responses to $\mathrm{PGE}_{2}$. $\star_{\mathrm{p}}<0.05 ;{ }^{\star \star} \mathrm{p}<0.005$.

with control $(p<0.05 ; n=6)$. After challenge with anti-IgE or fMLP tissue responsiveness to carbachol was not impaired indicating that the desensitisation observed was not a general phenomenon.

PHARMACOLOGICAL CHARACTERISATION OF MEDIATORS NEWLY SYNTHESISED OR RELEASED IN RESPONSE TO IMMUNE CELL ACTIVATION Antagonists were added 10 minutes before immune cell activation with anti-IgE or fMLP. Piroxicam $(10 \mu \mathrm{M})$, a cyclo-oxygenase inhibitor, was applied to the basolateral side of the tissues and significantly reduced basal SCC by $12.4(3.6) \mu \mathrm{A}(\mathrm{n}=12 ; \mathrm{p}<0.05$ compared with untreated controls). In paired tissues, piroxicam reduced anti-IgE stimulated $\Delta$ SCC by $91 \cdot 1(3.4) \%(p<0.005 ; n=5)$ and the fMLP stimulated $\triangle$ SCC response by $48 \cdot 2(25 \cdot 2) \%$ $(p<0.05 ; n=7$; Table IV). In contrast, pretreatment with piroxicam $(10 \mu \mathrm{M})$ significantly enhanced the $\triangle S C C$ response to exogenous prostaglandin $\mathrm{E}_{2}\left(\mathrm{PGE}_{2}\right)(10 \mu \mathrm{M}$, $\mathrm{p}<0 \cdot 005, \mathrm{n}=6$; Table IV). Piroxicam did not alter SCC responses to carbachol $(100 \mu \mathrm{M})$ added to the basolateral side of tissues at the end of each experiment ( $\triangle$ SCC control 53.4 $(7 \cdot 3) \mu \mathrm{A} ; \Delta \mathrm{SCC}$ piroxicam pretreated $59 \cdot 8$ $(7 \cdot 6) \mu \mathrm{A} ; \mathrm{n}=12$ ).

To investigate if histamine is a mediator of immune cell-dependent ion transport responses, tissues were pretreated with the $\mathrm{H}_{1}$ receptor antagonist mepyramine before antiIgE challenge. Mepyramine $(100 \mu \mathrm{M})$ reduced the basal SCC when compared with untreated controls ( $\triangle$ SCC mepyramine pretreated $-10 \cdot 1(3 \cdot 4) \mu \mathrm{A} ; \Delta S C C$ control $-2 \cdot 2(1 \cdot 6) \mu \mathrm{A}$; $\mathrm{p}<0.05, \mathrm{n}=12)$ and reduced the $\triangle \mathrm{SCC}$ response to anti-IgE by $79.6(12.0) \%$ (Table V). Mepyramine $(50 \mu \mathrm{M})$ had no significant effect on SCC responses to fMLP when compared with values obtained in paired controls. As mepyramine has anticholinergic properties, tissues were stimulated with carbachol (100 $\mu M)$ at the end of each experiment Mepyramine $(100 \mu \mathrm{M})$ did not effect SCC responses to carbachol, which were 98.3 $(17 \cdot 1) \%$ of responses obtained in non-pretreated, paired controls.

\section{Discussion}

The tissues used in this investigation were obtained from left or right colons at the time of surgical resection. Samples from the histologically normal margin were employed for ion 
TABLE V Effect of the $H_{1}$ antagonist mepyramine on short circuit current responses ( $\triangle S C C$ ) (values mean (SEM)

\begin{tabular}{llc}
\hline Stimulus & $\begin{array}{l}\text { Control } \\
\Delta S C C(\mu A)\end{array}$ & $\begin{array}{l}\text { Mepyramine } \\
\Delta S C C(\mu A)\end{array}$ \\
\hline Anti-IgE $(100 \mu \mathrm{g} / \mathrm{ml} ; \mathrm{n}=6)$ & $24 \cdot 1(9 \cdot 2)$ & $4 \cdot 2(2 \cdot 2)^{\star}$ \\
fMLP $(100 \mu \mathrm{M} ; \mathrm{n}=7)$ & $26 \cdot 0(9 \cdot 7)$ & $22 \cdot 1(7 \cdot 2)$ \\
Carbachol $(100 \mu \mathrm{M} ; \mathrm{n}=19)$ & $57 \cdot 4(9 \cdot 7)$ & $43 \cdot 8(5 \cdot 7)$ \\
\hline
\end{tabular}

$\triangle$ SCC responses to anti-IgE, fMLP and carbachol in mepyramine pretreated tissues compared with paired controls. Mepyramine significantly reduced responses to anti-IgE but not to fMLP or to carbachol.

${ }^{\star} \mathrm{p}<0.05$.

transport studies to investigate indirect stimulation of electrogenic ion transport. In Ussing chambers, after a typical stabilisation period, ${ }^{14}$ basal parameters were stable and comparable with values obtained in other studies on human colon. ${ }^{15-19}$ Differences in basal or stimulated ion transport have been reported when results obtained from tissues from ascending or descending colons were compared, ${ }^{20}$ although it is possible that the nutritional status of the tissue at time of resection contributes to these variations. ${ }^{21}$ Our findings indicate modest variation between tissues obtained from different segments of the colon in terms of basal parameters and responses to stimulation with directly acting secretagogues, for example, carbachol. However, SCC responses to activation of immunocytes were much more variable. This probably reflects variation in size and relative proportion of immune cell populations in the lamina propria from each donor. We therefore designed experiments using paired tissues from adjacent sites in order to have internal controls throughout. Furthermore, statistical analyses were performed using non-parametric tests.

Previous experiments using human colonic mucosae mounted on Ussing chambers have implicated neural and hormonal factors in modulating human intestinal ion transport. ${ }^{16-1922}$ To study the influence of cells of the immune system on transepithelial electrolyte movements we have used anti-human IgE and fMLP to activate mast cells and phagocytes respectively in isolated voltage clamped segments of human colon. Anti-IgE and fMLP evoked an increased or inward, rapid onset, monophasic $\triangle S C C$ in voltage clamped human colon.

The $\triangle S C C$ in response to anti-IgE and fMLP was, in each case, significantly attenuated by the loop blocking diuretic bumetanide, ${ }^{13}$ indicating that the SCC response to activation of mast cells and phagocytes is partly due to electrogenic chloride secretion. This supports the finding of Crowe and Perdue, ${ }^{23}$ who showed that anti-IgE stimulation of human colon was substantially reduced in chloride-free bathing solutions. Bumetanide also reduced ion transport responses to carbachol which have been shown to be accounted for by chloride secretion. ${ }^{19}$

Basolateral anti-IgE was much more effective in stimulating ion transport than apical application which produced only a modest change in SCC, an observation consistent with the stimulus having access to Fce-bearing cells within the lamina propria. However, fMLP applied apically produced a change in ion transport which was equivalent to $67 \%$ of responses obtained with a basolateral side challenge. Such a finding may result from fMLP acting on distinct (apical and basolateral) populations of phagocytes or, alternatively, fMLP applied to the apical domain will influence lamina propria cells by crossing the epithelial barrier. Although mast cells or phagocytes are not generally present in the lumen of normal human colon, ${ }^{24}$ the apical surface of epithelial cells lining the colonic crypts are exposed to large numbers of neutrophils and their secreted products during inflammation. ${ }^{25}$ Madara et al ${ }^{26} 27$ have shown that provision of activated neutrophils to the apical domain of cultured monolayers of colonic cells stimulated electrogenic chloride secretion. However, we found apical challenge with $\mathrm{fMLP}$ attenuated subsequent responses to basolateral challenge, presumably by desensitisation of a single exhaustable population of immunocytes which is influenced by the apical or basolateral addition of fMLP. This hypothesis is further supported by the observation that the magnitude of the SCC response to basolateral challenge was equivalent to the sum of the SCC responses to apical followed by basolateral challenge.

Lamina propria immune cells seemed to be desensitised after the stimuli employed in our experiments since significantly reduced SCC responses to repeated stimulation with antiIgE or fMLP were observed, although the capacity of the epithelial cells to respond to cholinomimetics was unimpaired. These findings may be explained as a consequence of depletion or exhaustion of immune cellderived mediators. Cross desensitisation was also observed between each of the stimuli. It is possible to conclude that neither anti-IgE nor fMLP activated mast cells or phagocytes exclusively. Eosinophils, have low affinity ${ }^{28}$ and high affinity $^{29}$ receptors for anti-IgE and eosinophil derived factors stimulate electrogenic chloride secretion across monolayers of human colonic epithelial cells. ${ }^{30}$ Although mast cells do not seem to respond to fMLP, ${ }^{11}$ activating factors for mast cells are released during stimulation of phagocytes. ${ }^{31}$ Thus, fMLP, by indirectly activating mast cells, may result in mast cells being refractory to further stimulation with anti-IgE.

Eicosanoids, including prostaglandins, induce chloride secretion in both animal colon $^{32}$ and epithelial monolayers, ${ }^{33}$ and are also locally synthesised in diseases associated with intestinal inflammation. ${ }^{34}$ Piroxicam, which inhibits mucosal prostaglandin synthesis, reduced the resting SCC, suggesting that basal generation of cyclo-oxygenase products may contribute to stimulation of the inward current in otherwise unstimulated preparations. Piroxicam also reduced the SCC response to each of the immunological stimuli employed. The concentration of piroxicam used had no effect on SCC responses to carbachol. Responses to $\mathrm{PGE}_{2}$ in the presence of piroxicam were significantly enhanced when compared with controls, which agrees with the 
findings of Keenan and Rangachari, ${ }^{35}$ who showed enhanced responsiveness of canine colonic epithelium in vitro to exogenous $\mathrm{PGE}_{2}$ during pharmacological inhibition of endogenous prostaglandin synthesis. These results suggest that eicosanoids are important as mediators or modulators of the secretory response to mast cell and phagocyte activation in humans, as has been described in other species. ${ }^{9}$

Histamine (acting through $\mathrm{H}_{1}$ receptors) stimulates chloride secretion in mammalian colon. ${ }^{36} 37$ The $\mathrm{H}_{1}$ receptor antagonist, mepyramine, which reduced SCC responses to histamine in human colon, ${ }^{38}$ attenuated the SCC response to anti-IgE but not to fMLP. Although high concentrations of mepyramine were used, these were without effect on SCC responses to carbachol $(100 \mu \mathrm{M})$. Presumably, anti-IgE cross links cell-surface IgE to activate mast cells which release histamine in quantities sufficient to stimulate chloride secretion.

In summary, we have used human tissues to show that electrogenic ion transport responses, at least partly due to chloride secretion, may be produced by both mast cell and phagocyte stimulation. Activated mast cells produce an array of mediators ${ }^{39}$ which can provoke intestinal chloride secretion when applied individually to animal colonic mucosa or epithelial monolayers mounted in Ussing chambers. ${ }^{25}$ In man, mast cells are thought to play an important role in the pathogenesis of a number of conditions in which diarrhoea may be a prominent feature. These include food allergies, ${ }^{2}$ systemic mastocytosis, ${ }^{40}$ and idiopathic inflammatory bowel diseases such as Crohn's disease and ulcerative colitis. ${ }^{41} 42$ Mucosal infiltration with phagocytes (neutrophils, eosinophils, and macrophages), is a feature of several intestinal inflammatory diseases of which diarrhoea may be a symptom. Our findings are in keeping with data obtained using rabbit colonic mucosae which have shown that fMLP-activated phagocytes evoked electrogenic chloride secretion partly mediated by eicosanoid production, and amplified through local enteric nerves. ${ }^{9}$ Studies using a human colonic epithelial cell line have shown that products of activated neutrophils may directly induce chloride secretion. ${ }^{26} 27$

Immunophysiological regulation of intestinal function is a rapidly growing area of interest. ${ }^{4344}$ This study provides important evidence that immune cells may regulate human colonic epithelial ion transport. Future investigations may elucidate mechanisms by which populations of intestinal immune cells interact with each other and the local enteric nervous system in the regulation of ion transport, in both normal and disease states. A better understanding of this cell to cell interaction may lead to newer strategies for the treatment of diarrhoeal disease.

We thank the members of the Surgery and Pathology Departments at St Vincent's Hospital, Dublin, for their enthusiastic cooperation with this study.

This work was supported by the Irish Health Research Board and by a grant from the Wellcome Trust (AWB).

A preliminary report of this work has been presented at the American Gastroenterology Association (May 1993).
1 Field M, Rao M, Chang EB. Intestinal electrolyte transport and diarrhoeal disease (part 2). New Engl f Med 1989; 321: 879-83.

2 Barrett KE. Mechanisms of inflammatory diarrhoea. Gastroenterology 1992; 103: 710-11.

3 Crowe SE, Perdue MH. Gastrointestinal food hypersensitivity: basic mechanisms of pathophysiology Gastroenterology 1992; 103: 1075-95.

4 Powell DW. Immunophysiology of intestinal electrolyte transport. In: Schultz SG, ed. Handbook of physiology. The Gastrointestinal system IV. Rockville, MD: The American Physiologic Society, 1991: 591-641.

5 Castro GA. Immunological regulation of electrolyte transport. In: Lebenthal E, Duffey ME, eds. Textbook of secretory diarrhoea. New York: Raven Press, 1990: 31-46.

6 Baird AW, Cuthbert AW, Pearce FL. Immediate hypersensitivity reactions the epithelia from rats infected with nippostrongylus brasiliensis. $B r f$ Pharmacol 1985; 85: 787-95.

7 Crowe SE, Sestini P, Perdue MH. Allergic reactions of rat jejunal mucosa. Ion transport responses to luminal antigen and inflammatory mediators. Gastroenterology 1990; 99: 74-82.

8 Russell DA, Castro GA. Anaphylactic-like reaction of small intestinal epithelium in parasitised guinea pigs. Immunology 1985; 54: 573-9.

9 Bern MJ, Sturbaum CW, Karayalcin SS, Berschneider HM, Wachsman JT, Powell DW. Immune control of rat and rabbit colonic electrolyte transport: role of prostaglandins and enteric system. F Clin Invest 1989; 83: 1810-20.

10 Barrett KE. Immune related intestinal chloride secretion. III Acute and chronic effects of mast cell mediators on chloride secretion by a human colonic epithelial cell line. chloride secretion by a human

11 Fox CC, Dvorak AM, Peters SP, Kagey-Sobotka A, Lichtenstein LM. Isolation and characterisation of human intestinal mast cells. $\mathcal{F}$ Immunol 1985; 135: 483-91.

12 Niedel JE, Cuatrecasas P. Formyl peptide chemotactic receptors of leucocytes and macrophages. In: Horecker $\mathrm{BL}$, Stadtman R, eds. Current topics in cellular regulation. New York: Academic Press, 1980; 17: 137-70.

13 O'Grady SM, Palfrey HC, Field M. Characteristics and functions of the Na-K-Cl cotransporter in epithelial functions of the Na-K-Cl cotransporter
tissues. Am $\mathcal{f}$ Physiol 1987; 253: C177-92.

14 Hegel U, Fromm M. Electrical measurements in large intestine. Methods Enzymol 1990; 192: 459-84.

15 Grady GF, Duhamel RC, Moore EW. Active transport of sodium by human colon in vitro. Gastroenterology 1970; 59: 583-88.

16 Rask-Madsen J, Hjelt K. Effect of amiloride on electrical activity and electrolyte transport in human colon. Scand $\mathcal{F}$ Gastroenterol 1977; 12: 1-6.

17 Hubel KA, Renquist K, Shirazi S. Ion transport in human caecum, transverse colon and sigmoid colon in vitro; baseline and response to electrical stimulation of intrinsic nerves. Gastroenterology 1987; 92: 501-7.

18 Sellin JH, De Soigne R. Ion transport in the human colon in vitro. Gastroenterology 1987; 93: 441-8.

19 Zimmerman TW, Binder HJ. Effect of tetrodotoxin on cholinergic agonist-mediated colonic electrolyte transport. Am F Physiol 1983; 244: G386-91.

20 Sandel GI, Wills NK, Alles W, Binder HJ. Electrophysiology of the human colon: evidence of segmental heterogeneity. Gut 1986; 27: 999-1005.

21 Sagmanligil V, Levin RJ. Electrogenic ion secretion in proximal, mid and distal colon from fed and starved mice. Comp Biochem Physiol (C) 1993; 106: 449-56.

22 Kuwahara A, Cooke HJ, Carey HV, Mekhjian H, Ellison EC, McGregor B. Effects of enteric neural stimulation on chloride transport in human left colon in vitro. Dig Dis Sci 1989; 34: 206-13.

23 Crowe SE, Perdue MH. Anti-Immunoglobulin E stimulated ion transport in human large and small intestine. Gastroenterology 1993; 105: 764-72.

24 Levine D, Haggitt R. Normal histology of the colon. Am F Surg Pathol 1989; 13: 966-84.

25 Yardley JH. Pathology of idiopathic inflammatory bowel disease and relevance of specific cell findings: an overview. In: Recent developments in the therapy of inflammatory bowel In: Recent developments in the therapy of inflammatory bowel
disease. Proceedings of a symposium. Myerhoff centre for disease. Proceedings of a symposium. Myerhoff centre for
digestive diseases at Johns Hopkins, Baltimore. 1986: 3-9.

26 Madara JL, Parkos CA, Colgan SP, Macleod RJ, Nash S, Matthews J, et al. Chloride secretion in a model intestinal epithelium induced by a neutrophil derived secretagogue. fClin Invest 1992; 89: 1938-44.

27 Madara JL, Patapoff TW, Gillece-Castro B, Colgan SP, Parkos CA, Delp C, et al. 5' adenosine monophosphate is the neutrophil derived paracrine factor that elicits chloride secretion from T84 intestinal epithelial cell monolayers. $\mathcal{F}$ Clin Invest 1993; 91: 2320-5.

28 Capron M, Capron A, Dessaint JP, Torpier G, Gunner S, Johannson SG, et al. Fc receptors for IgE on human and Johannson SG, et al. Fc receptors for IgE on huma
rat eosinophils. $\mathcal{F}$ Immunol 1981; 126: 2087-92.

29 Gounni AS, Lamkhioued B, Ochial K, Tanaka Y, Delaporte E, Capron A, et al. High affinity IgE receptor on eosinophils is involved in defence against parasites. Nature 1994; 367: 183-6.

30 Resnic M, Colgan SP, Weller J, Madara JL. Activated eosinophils evoke $\mathrm{Cl}$ secretion via adenosine-like receptors in a model intestinal epithelium. Gastroenterology 1993; 104: A769.

31 Lett-Brown MA, Alam R, Grant JA. Regulation of human basophils and mast cells. Activation by cytokines. In Cruse J, Lewis $\mathrm{R}$ Jr, eds. The year in immunology, 1988. 
Immunoregulatory cytokines and cell growth. Basel: Karger, 1989: 195-204.

32 Wardle TD, Hall L, Turnberg LA. Inter-relationships between inflammatory mediators released from colonic mucosa in ulcerative colitis and their effects on colonic secretion. Gut 1993; 34: 503-8.

33 Weymer A, Huott P, Liu W, McRoberts JA, Dharmsathaphorn $K$. Chloride secretory mechanism induced by prostaglandin $\mathrm{E}_{1}$ in a colonic epithelial cell line. $₹$ Clin Invest $1985 ; 75$ : $1828-36$.

34 Hawkey CJ, Rampton DS. Prostaglandins and the gastrointestinal mucosa, are they important in its funcgastrointestinal mucosa, are they important in its func-
tion, disease or treatment? Gastroenterology 1985; 89: tion, dise

35 Keenan CM, Rangachari PK. Eicosanoid interactions in the canine proximal colon. Am f Physiol 1989; 256: G673-9.

36 McCabe RD, Smith PL. Effects of histamines and histamine receptor antagonists on ion transport in rabbit descending colon. Am $\mathcal{F}$ Physiol 1984; 246: G411-8.

37 Wang YZ, Cooke HJ, Su HC, Fertel R. Histamine augments colonic secretion in guinea pig distal colon. $A m$ f Physiol 1990; 258: G432-9.

38 Keely SI, Stack WA O'Donoghue DP, Baird AW. Histamine stimulation of human colonic ion transport is mediated via $\mathrm{H}_{1}$ receptors. Br $\mathcal{F}$ Pharmacol 1993; 110: 79P

39 Befus AD, Dyck N, Goodacre R, Bienenstock J. Mast cells from the human intestinal lamina propria. Isolation, histochemical subtypes and functional characterisation. $\mathcal{f}$ Immunol 1987; 138: 2604-10.

40 Cherner JA, Jensen RT, Dubois A, O Dorisio TM, Gardner $\mathrm{JD}$, Metcalfe DD. Gastrointestinal dysfunction in systemic mastocytosis: a prospective study. Gastroenterology temic mastocytosis:

41 Dvorak A, Monohan R, Osage J, Dickerson G. Crohn's disease: transmission electron microscopic studies. Immunologic inflammatory response. Alteration of mast cells, basophils, eosinophils and microvasculature. Hum Pathol 1980; 11: 606-19.

42 Balazs M, Illyes G, Vadasz G. Mast cells in ulcerative colitis. Quantitative and ultrastructural studies. Virchows Arch Cell Path 1989; 57: 353-60.

43 Castro GA, Arntzen CJ. Immunophysiology of the gut: a research frontier for integrative studies of the common mucosal immune system. Am $\mathcal{f}$ Physiol 1993; 265: G599-610.

44 Kagnoff MF. Immunology of the intestinal tract. Gastroenterology 1993; 105: 1275-80. 